\title{
Development of Plant Organ Scrapbook Learning Media in Elementary School
}

\author{
AUTHOR \\ Tiara Ayu Eka Putri ${ }^{1}$, Nataria Wahyuning Subayani ${ }^{2}$, Iqnatia Alfiansyah ${ }^{3}$ \\ PGSD Program, Universitas Muhammadiyah Gresik \\ tiara33356@gmail.com, nataria.nata@umg.ac.id, iqnatia@umg.ac.id
}

\begin{abstract}
Development of Plant Organ Scrapbook Learning Media in Elementary Schools. This study aims to develop learning media for scrapbooking plant organs and knowing (1) Validation of scrapbooks of plant organs, (2) student responses to scrapbooking of plant organs. This research is a development research that uses a 4D model, consisting of Definition, Design, Development, and Desseminate which is modified by the researcher. The subject of this study was addressed to the fourth grade students of UPT SD Negeri 30 Gresik with a total of 10 students. The instruments used were interview sheets, validation sheets, and questionnaire sheets. The results obtained include, 1) Scrapbook of plant organs obtained $90.75 \%$ results, with very valid criteria. The validator states that the plant organ Scrapbook is very valid with few revisions and deserves to be tested. 2) Scrapbook of plant organs obtained $95.5 \%$ results, with very good criteria. So that the plant organ scrobook can be used in the learning process as a learning tool or media learning.
\end{abstract}

Keywords: 4D model, Scrapbook of plant organs

\section{INTRODUCTION}

Learning media is part of learning tools, therefore it is necessary to use interesting learning tools and be able to increase students' enthusiasm for learning, especially in elementary schools. Science is a very important subject and includes lessons that must be learned. Science helps students to get to know about the facts about nature and everything in it. Based on the results of interviews with elementary school level children, many like science learning because it is an interesting lesson that is introduced to the environment and the earth and its contents. Although some of them feel that science material is material that has a lot of notes and memorization. The results of interviews conducted by researchers with science teachers at UPT SD Negeri 30 Gresik, students did not understand the material in learning about plant organs. In the sense that students understand about plant organs found in the environment around the school only. students usually learn with textbook guides and the teacher invites students to directly introduce plant organs around the school environment. so researchers want to innovate by developing learning media for plant organs. 
The media that will be developed by the researcher is scrapbook. Scrapbook is a book in which there are illustrated images where there is art to stick images on paper media and decorate them so that they become creative works. This scrapbook contains the classification of plants. The development of this scrapbook is one of the efforts in facilitating the learning process. The existence of media developed by researchers is expected to be able to improve the skills of students in explaining plant organs and their functions. The forms and images in the media are expected to increase the interest and motivation of students in learning about plant organs.

A. Theoretical Framework

In order to optimize the skills of explaining the material on plant organs, teachers need to use appropriate and interesting media for students. Researchers use interesting media in learning plant organs in elementary schools. Before developing the media, the researcher identified the needs of students to obtain data that supports development through interviews with Natural Science subject teachers.

The selected media is scrapbook media. The selection of this media is in accordance with the background of the problem. Then the researchers formulated the objectives, materials, and success measurement tools. Furthermore, the researchers designed and made a scrapbook media, the media was validated with a validator to obtain suggestions and improvements. After the repair, the researchers tested the media to elementary school education lecturers and Natural Science subject teachers to determine the success of using scrapbook media in plant organ material.

\section{METHODS}

A. The research procedure carried out by the researcher is using a 4-D model developed by (Thiagarajan, 1974) which includes several stages, namely the definition stage, the design stage, the development stage, and the dissemination stage. ), but not at this stage). The following is an explanation of the 4-D development stage that will be carried out by researchers:

1. Define

At this stage is the initial stage to develop scrapbook learning media.

2. Design

At this stage, it aims to prepare learning tools.

3. Develope

a. Media validation

Validation tests are carried out by experts. Validation was carried out by two elementary school teacher education lecturers and two Natural Science subject teachers from UPT SD Negeri 30 Gresik. The validators are those who have experts and understand learning media that are suitable for the character of students and are able to provide feedback or suggestions about media that have been developed for the sake of media perfection.

b. Revision

Learning media is improved according to the assessment score and input or 
suggestions that have been given by the validator after conducting an assessment of the developed media.

c. Test

Learning media that have been improved need to be tested to determine the effectiveness of the media. The test phase was carried out by giving a questionnaire containing a statement about the learning media for plant organ scrapbooks.

\section{Disseminate}

After the validation results show that the media is valid, effectively used and the student's response is positive, the media will be disseminated.

\section{B. Technique dan Instrument of Data Collection}

\section{Data Collection Technique}

a) Interview

To find out the needs and characteristics of students and as a reference in the process of developing scrapbook media, interview techniques can be used. Interviews were conducted twice, namely before the researcher developed the media and after the media was developed. Interviews were conducted by using a list of questions that had been prepared by the interviewer so that the questions to be asked were definite and clear. Interviews were conducted with teachers of Natural Sciences at UPT SD Negeri 30 Gresik.

b) Media Validation

Validation in this research is done by validating the media to validators who are experienced in the teaching and learning process. Each validator is asked to rate the media that has been developed. The validation test was carried out by researchers to four validators, namely two elementary school teacher education lecturers who assessed aspects of linguistic feasibility and graphic aspects, then two teachers of UPT SD Negeri 30 Gresik who assessed aspects of content feasibility and linguistic feasibility.

c) Response Questionnaire

The questionnaire technique in this study was carried out by asking for responses from 25 fourth grade students of UPT SD Negeri 30 Gresik in the form of a questionnaire sheet and asked to provide responses to the media.

\section{Instrument of Data Collection}

a) Interview sheet

The results of the interviews were described in descriptive sentences, then conclusions were obtained regarding the results of the identification of the characteristics and needs of 
students and could generate ideas for researchers regarding the development of appropriate media for learning.

b) Media validation sheet

The validation sheet is used to assess the quality of the developed media, so that it can be seen the suitability of the media to the learning material and obtain suggestions and improvements to the media. There are 4 validation sheets used, namely the validation sheet for the linguistic feasibility aspect, the validation for the graphic aspect, the validation for the content feasibility aspect, and the validation for the presentation feasibility aspect.

c) Questionnaire

This questionnaire was given to 25 fourth grade students at SD Negeri 30 Gresik after the media was tested as a way of obtaining data.

\section{Analisis dan Keabsahan Data}

1) Analysis interview results

The data from the interviews were analyzed descriptively or drew conclusions from the answers of the informants. Then the answers are elaborated so that descriptive data is obtained from the identification of the characteristics and needs of students.

2) Analysis validation results

The data from the validation of the plant organ scrapbook media were then analyzed using the data processing formula.

Validation $(V)=\frac{\text { Total Score Validation }}{\text { Total Score Maks }} \times 100 \%$

(Akbar, 2013)

Average value $=\frac{\text { total value }}{\text { number of validators }}$

Table 3.1 Qualification level validity

\begin{tabular}{|c|c|}
\hline Score & Criteria \\
\hline $85 \%-100 \%$ & Very Valid \\
\hline $69 \%-84 \%$ & Valid \\
\hline $53 \%-68 \%$ & Enough Valid \\
\hline $36 \%-52 \%$ & Less Valid \\
\hline $20 \%-36 \%$ & Not Valid \\
\hline
\end{tabular}

(B. Subali, dkk, 2012)

Conclusions regarding the results of scrapbook media validation if a score of 69 is obtained, the media is said to be valid. 
3) Analysis response questionnaire result

According to (Arikunto, 2007) data analysis using a questionnaire there are five levels, each alternative is given the following meaning:
1.) $\mathrm{SS}$
$=$ Very agree, rated 5
2.) $\mathrm{S}$
$=$ Agree, rated 4
3.) $\mathrm{KS}$
$=$ Enough agree, rated 3
4.) $\mathrm{TS}$
$=$ Not agree, rated 2
5.) STS
$=$ Not very agree, rated 1

Presentase PD $=\frac{(5 x S S)+(4 x S)+(3 x k s)+(2 x T S)+(1 x S T S)}{\left(5 x \sum n\right) \times \text { Jumlah peserta didik }} \times 100 \%$

The provisions in giving meaning use the criteria for the level of achievement as follows :

Table 3.2 Qualification level achievement

\begin{tabular}{|c|c|}
\hline Score & Criteria \\
\hline $81 \%-100 \%$ & Very Good \\
\hline $61 \%-80 \%$ & Good \\
\hline $41 \%-60 \%$ & Enough Good \\
\hline $21 \%-40 \%$ & Less Good \\
\hline $0 \%-20 \%$ & Not Good \\
\hline
\end{tabular}

(Arikunto, 2010)

If the student's response reaches more than $61 \%$, it can be concluded that the scrapbook media is good, meaning that it can be used in the learning process.

\section{RESULT AND DISCUSSION}

The plant organ scrapbook media has been tested for success through a validation process for lecturers, teachers and students to determine the validity and effectiveness of learning media in class IV UPT SD Negeri 30 Gresik. The results of this study use the theory developed by Thiagarajan, namely the 4-D model which was carried out in 3 stages including the definition stage, the design stage, and the development stage with modifications made by researchers. The plant organ scrapbook media that has been designed is validated by the validator. The validators who assessed the plant organ scrapbook for grade IV were two Elementary School Teacher Education lecturers, namely Mr. Arya Setya Nugroho, M.Pd and Mr. Afakhrul Masub Bakhtiar, M.Pd and two UPT teachers of SD Negeri 30 Gresik, namely Mrs. Evi Yuliyanti, S.Pd and Mrs. Lilik History, S.Pd. The validator assesses the media by placing a check mark on the scoring score. The validator provides suggestions or comments that are expressed in writing which will be used as a basis for making improvements and enhancements to the plant organ scrapbook media. The validation results are converted into 
numbers to simplify the calculation process. The results of the validation carried out are assessing several aspects including, linguistic feasibility aspects, graphic aspects, content feasibility aspects, and presentation feasibility aspects are presented in the following table:

Table 3.1 Validator Assessment Results Aspect of Language on The Plant Organ Scrapbook

\begin{tabular}{|l|l|c|}
\hline No. & \multicolumn{1}{|c|}{ Rated Aspect } & Score \\
\hline 1. & Use of the right words & 5 \\
\hline 2. & Sentence structure accuracy & 5 \\
\hline 3. & Sentence effectiveness & 5 \\
\hline 4. & Conformity with intellectual development & 4 \\
\hline
\end{tabular}

$$
\begin{array}{ll}
\text { Validation } & =\frac{\text { Total Score Validation }}{\text { Total ScoreMaks }} \times 100 \% \\
\text { Validation } & =\frac{19}{20} \times 100 \% \\
\text { Validation } & =95 \%
\end{array}
$$

Table 3.2 Validator Assessment Results Aspect of Graphic on The Plant

Organ Scrapbook

\begin{tabular}{|l|l|c|}
\hline No. & \multicolumn{1}{|c|}{ Rated Aspect } & Score \\
\hline 1. & Cover scrapbook & 5 \\
\hline 2. & Layout scrapbook & 4 \\
\hline 3. & Content illustration scrapbook & 4 \\
\hline 4. & Print scrapbook & 4 \\
\hline 5. & Binding scrapbook & 5 \\
\hline
\end{tabular}

$$
\begin{aligned}
\text { Validation } & =\frac{\text { Total Score Validation }}{\text { Total ScoreMaks }} \times 100 \% \\
\text { Validation } & =\frac{22}{25} \times 100 \% \\
\text { Validation } & =88 \%
\end{aligned}
$$

Table 3. 3 Validator Assessment Results Aspect of Content Eligibility on The Plant

\section{Organ Scrapbook}


UMGCINMATIC : $1^{\text {st }}$ Rethinking Education during Covid-19 Era: Challange and Innovation Volume 1 No 2

\begin{tabular}{|c|l|c|}
\hline No. & \multicolumn{1}{|c|}{ Rated Aspect } & Score \\
\hline 1. & Completeness of learning materials & 4 \\
\hline 2. & Depth of learning materials & 4 \\
\hline 3. & Concept accuracy & 4 \\
\hline 4. & The suitability of the sample with the material & 5 \\
\hline 5. & Literacy empowerment & 5 \\
\hline
\end{tabular}

$\begin{aligned} \text { Validation } & =\frac{\text { Total Score Validation }}{\text { Total ScoreMaks }} \times 100 \% \\ \text { Validation } & =\frac{22}{25} \times 100 \% \\ \text { Validation } & =88 \%\end{aligned}$

Table 3.4 Validator Assessment Results Aspect of Presentation Feasibility on The Plant Organ Scrapbook

\begin{tabular}{|c|l|c|}
\hline No. & \multicolumn{1}{|c|}{ Rated Aspect } & Score \\
\hline 1. & Consistency of understanding & 4 \\
\hline 2. & Student centered & 4 \\
\hline 3. & Encourage curiosity and critical thinking & 5 \\
\hline 4. & Completeness of the preface and table of contents & 5 \\
\hline 5. & Completeness of the contents & 5 \\
\hline
\end{tabular}

$\begin{array}{ll}\text { Validation } & =\frac{\text { Total Score Validation }}{\text { Total ScoreMaks }} \times 100 \% \\ \text { Validation } & =\frac{23}{25} \times 100 \% \\ \text { Validation } & =92 \%\end{array}$

From the results of the table above, the average validation value is $90.75 \%$. By obtaining a percentage of $90.75 \%$, the plant organ scrapbook media is included in the very valid criteria of the specified standard, which is $69 \%$ (According to B.Subali, 2012). From the above results indicate that the plant organ scrapbook media is said to be very valid.

The response questionnaire stage was carried out by distributing student response questionnaires to assess the effectiveness of the plant organ scrapbook media. The response questionnaire consists of 9 statements given. Students fill out a response questionnaire by placing a check mark in the student response column. The following are the results of the student response questionnaires: 
Table 3.6 The Results of Obtaining Student Response Questionnaires

\begin{tabular}{|c|c|c|c|c|c|c|}
\hline No. & Student Name & SS & $\mathrm{S}$ & KS & TS & STS \\
\hline 1. & AA & 7 & 2 & - & - & - \\
\hline 2. & $\mathrm{AF}$ & 6 & 3 & - & - & - \\
\hline 3. & AND & 6 & 3 & - & - & - \\
\hline 4. & APNA & 7 & 2 & - & - & - \\
\hline 5. & AS & 8 & 1 & - & - & - \\
\hline 6. & ASR & 7 & 2 & - & - & - \\
\hline 7. & BS & 7 & 2 & - & - & - \\
\hline 8. & BZL & 8 & 1 & - & - & - \\
\hline 9. & DA & 7 & 2 & - & - & - \\
\hline 10. & ERP & 5 & 4 & - & - & - \\
\hline 11. & $\mathrm{FI}$ & 6 & 3 & - & - & - \\
\hline 12. & FNN & 6 & 3 & - & - & - \\
\hline 13. & GRN & 7 & 2 & - & - & - \\
\hline 14. & IDR & 7 & 2 & - & - & - \\
\hline 15. & $\mathrm{IIH}$ & 8 & 1 & - & - & - \\
\hline 16. & LF & 7 & 2 & - & - & - \\
\hline 17. & MFB & 6 & 3 & - & - & - \\
\hline 18. & MHS & 7 & 2 & - & - & - \\
\hline 19. & MNA & 5 & 4 & - & - & - \\
\hline 20. & MNH & 7 & 2 & - & - & - \\
\hline 21. & NKS & 4 & 5 & - & - & - \\
\hline 22. & NS & 5 & 4 & - & - & - \\
\hline 23. & SA & 8 & 1 & - & - & - \\
\hline
\end{tabular}


UMGCINMATIC : $1^{\text {st }}$ Rethinking Education during Covid-19 Era: Challange and Innovation Volume 1 No 2

\begin{tabular}{|c|c|c|c|c|c|c|}
\hline 24. & SN & 6 & 3 & - & - & - \\
\hline 25. & TM & 8 & 1 & - & - & - \\
\hline \multicolumn{2}{|c|}{ Total } & 165 & 60 & & & \\
\hline
\end{tabular}

From the table above shows the results of the questionnaire responses obtained by many students who chose strongly agree (SS) and agree (S). The percentage calculation obtained is as follows:

$$
\begin{array}{ll}
\text { PD } & =\frac{(5 x S)+(4 \times S)+(3 \times k s)+(2 \times T S)+(1 \times S T S)}{\left(5 \times \sum n\right) \times \text { student total }} \times 100 \% \\
\text { PD } & =\frac{(5 \times 165)+(4 \times 60)+(3 \times 0)+(2 \times 0)+(1 \times 0)}{(5 \times 9) \times 25} \times 100 \% \\
\text { PD } & =\frac{835+240}{1125} \times 100 \% \\
\text { PD } & =\frac{1075}{1125} \times 100 \% \\
\text { PD } & =95,5 \%
\end{array}
$$

The results of these calculations indicate that the percentage generated from the student response questionnaire is $95.5 \%$, meaning that it meets the specified criteria, namely $61 \%$ where the plant organ scrapbook media is very good (according to Arikunto, 2010), meaning that it can be used in the learning process.

\section{CONCLUSION}

Based on the results of the researchers, the conclusion in this study is that the scrapbook media of plant organs was developed with reference to the modified and simplified Thiagarajan (4-D models) development model. This development research only carried out three stages, namely the first stage of defining (Define) consisting of five steps, namely: front end analysis, student analysis, concept analysis, task analysis, and formulation of learning objectives, second stage of design (Design) to prepare media development learning. This stage consists of steps, namely: selection of learning media, selection of formats, and planning of initial media design, the three stages of development (Develope) the development stage consists of three steps, namely validation followed by revision and development trials. The scrapbook was validated by four validators, namely the linguistic aspect validator, the graphic aspect validator, the content feasibility aspect validator, and the presentation feasibility aspect validator. From the results of the four validators, the plant organ scrapbook learning media is said to be very valid because it obtains a percentage of $90.75 \%$. Then the learning media scrapbook plant organs can be tested. The results of the analysis of student responses using a response questionnaire of $95.5 \%$ fall into the very good category. So it can be concluded that the scrapbook of plant organs for grade IV elementary school can be used in the learning process as a learning tool or resource.

Suggestions based on the description of the research results, the researchers can provide the following suggestions: For teachers, using plant organ scrapbook media for learning plant organs and their functions in elementary schools and for further researchers, it is hoped that 
the development of plant organ scrapbook media can be further developed and more interesting for students. learners.

\section{REFERENCE}

Akbar, S. (2013). Instrumen Bahan Ajar. Bandung: Remaja Rosdakarya.

Arikunto. (2007). Evaluasi Pembelajaran. Jakarta: PT Rineka Cipta.

Arikunto. (2010). Evaluasi Pembelajaran. Jakarta : PT Rineka Cipta.

Arsyad. (2014). Media Pembelajaran. Jakarta: PT RajaGrafindo Persada.

Arsyad. (2019). Media Pembelajaran. Depok: PT RajaGrafindo Persada.

Dewi. (2017). Pengembangan Media Pembelajaran Scrapbook Materi Karangan Deskriptif Mata Pelajaran Bahasa Indonesia Kelas III Sekolah Dasar. Refleksi Edukatika: Jurnal Ilmiah Kependidikan.

Hardiana. (2015). Terampil Membuat 42 Kreasi Mahar Scrapbook. Jakarta: Gramedia Pustaka Umum.

Purwono, U. (2008). Aspek Kelayakan Isi Menurut BSNP. Lumbung Pustaka UNY.

Reece, N. A. (2008). BIOLOGI Edisi Kedelapan. Jakarta: Erlangga.

Rosyana, V. (2018). Pengembangan Media Pembelajaran Scrapbook Untuk Meningkatkan Pengetahuan Terhadap Bencana Gempa Bumi pada Siswa Kelas VII di SMP Negeri 3 Sawit Boyolali. Jurnal Ilmiah Kependidikan, 7.

Sadiman. (2018). Media Pendidikan. Jakarta: PT RajaGrafindo Persada.

Samatowa, U. (2016). Pembelajaran IPA di Sekolah Dasar. Jakarta: PT Indeks.

Saputra, R. E. (2020). Pengembangan Media Pembelajaran Scrapbook pada Materi Sistem Pencernaan Manusia Kelas V SDN Gisikdrono 03 Kota Semarang. Jurnal Ilmiah Kependidikan.

Sari, D. L. (2018). Pengaruh Media Scrapbook Terhadap Hasil Belajar IPA Materi Sumber Energi Siswa Kelas IV SDN Lidah Kulon IV Surabaya. Jurnal Ilmiah Kependidikan, 701.

Sugiyono. (2012). Memahami Penelitian Kualitatif. Bandung: Alfabeta.

Sukmasari, S. F. (2020). Pengembangan Modul Ajar IPS Berbasis Keragaman Suku Bangsa di Jawa Timjur untuk Kelas IV SD.

Thiagarajan, S. (1974). Instructional Development for Training Teachers of Expectional Children a Sourcebook. Minnesota: Indiana Univercity.

Tiara Kusnia, R. Y. (2018). Pengembangan Media Pembelajaran Scrapbook Materi Karangan Deskripsi Mata Pelajaran Bahasa Indonesia Kelas III Sekolah Dasar. Refleksi Edukatika: Jurnal Ilmiah Kependidikan, 22.

Tjitrosoepomo, G. (2005). Morfologi Tumbuhan. Yogyakarta: Gadjah Mada University.

Trianto. (2015). Media Pembelajaran Terpadu: Konsep, Strategi, dan Implementasinya dalam Kurikulum Tingkat Satuan Pendidikan (KTSP). Jakarta: Bumi Aksara. 